\title{
"Beauty is Truth and Truth Beauty": How Intuitive Insights Shape Legal Reasoning and the Rule of Law
}

\author{
Stephen M. Maurer*
}

\begin{abstract}
Scientists have long recognized two distinct forms of human thought. "Type 1" reasoning is unconscious, intuitive, and specializes in finding complex patterns. It is typically associated with the aesthetic emotion that John Keats called "beauty." "Type 2" reasoning is conscious, articulable, and deductive. Scholars usually assume that legal reasoning is entirely Type 2. However, critics from Holmes to Posner have protested that unconscious and intuitive judgments are at least comparably important. This Article takes the conjecture seriously by asking what science can add to our understanding of how lawyers and judges interpret legal texts.

The analysis is overdue. Humanities scholars have long invoked findings from cognitive psychology, brain imaging, and neural network theory to argue that postmodern interpretations that ignore texts in favor of politics and cultural explanations are hopelessly incomplete. Similar arguments should be a fortiori stronger in law, where judges and scholars routinely stress the detailed wording of texts.

The Article begins by reviewing previous attempts to apply literary theory to legal texts. We argue that the main failing of this literature is that it says little or nothing about how judges and advocates choose between competing legal interpretations. Section II argues that the best way to fill this gap is to ask what scientists have learned about the brain. This includes the fundamental insight that most human thought processes rely on both Type 1 and Type 2 methods. The Article also documents the surprising cognitive psychology result that Type 1 judgments show significant universality, i.e. that humans who study subjects for long periods often
\end{abstract}

* Emeritus Adjunct Professor of Public Policy, smaurer@berkeley.edu. I thank the friends of my misspent youth at Lasky, Haas, Cohler \& Munter (Mitchell Chyette), Brown \& Bain (Kenneth S. Rosenblatt) and Harvard Law School (Randall K. Morck) who kept my interest in this topic alive. Additional thanks to Daniel Chen, Neal Gandal, and Alex Karepetian for their insightful comments. 
make similar choices without regard to the societies they were born into. Section III extends these arguments to law by arguing that legal judgment frequently turns on the brain's Type 1 pattern recognition machinery. The next two Sections build on this foundation to construct an explicit theory of how Type 1 thinking enters into legal reasoning and outcomes. Section IV begins by reviewing nineteenth century theories that claimed a leading role for intuitive reasoning in public policy. Section $\mathrm{V}$ updates these theories to accommodate the relatively weak statistical correlations that psychologists have documented, arguing that modern court systems amplify these signals in approximately determinate ways. It also explains why court systems that emphasize close textual analysis are able to resist erosion from competing incentives like cronyism and judicial activism. Section VI builds on these theory insights to suggest specific policy prescriptions.

\section{CONTENTS}

ABSTRACT .................................................................... 129

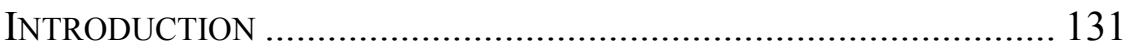

I. THE LAW-AND-LiTERATURE DEBATE.................................... 134

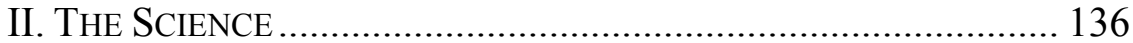

A. Type Intuition: Aesthetics and Fast Thinking .................... 138

1. Brain Imaging ............................................................ 139

2. Neural Networks......................................................... 140

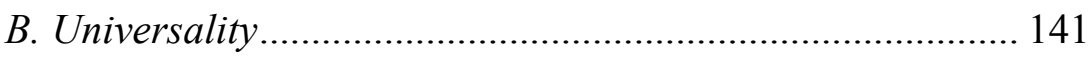

1. Objective Problems .................................................... 141

2. Aesthetic Convergence............................................... 142

3. Origins ........................................................................ 143

4. Education and Socialization ......................................... 144

III. TYPE 1 THINKING IN LAW ................................................. 145

A. The Subjective Experience of Law ................................... 145

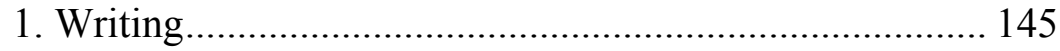

2. Legal Writing.............................................................. 146

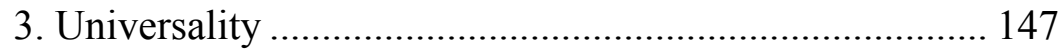

4. Normative Implications ............................................ 147 
B. Mechanics: Finding Alternative Patterns......................... 148

C. Legal Judgment: Choosing the Best Pattern ..................... 149

Education and Socialization ............................................ 150

IV. TOWARD A TYPE 1 THEORY OF LAW: INDIVIDUALS............... 151

A. Victorian Theory: Shelley, Arnold, and Holmes .................. 151

B. Updating the Theory ...................................................... 152

C. The Subjective Experience of Law................................... 153

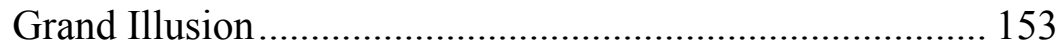

V. TOWARD A TYPE 1 TheORY OF LAW: InSTITUTIONS ............... 154

A. What Does "Rule of Law" Require? ................................ 154

B. Is Formalism Stable? ...................................................... 154

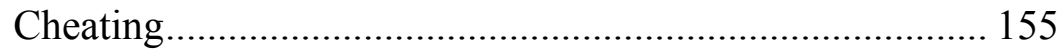

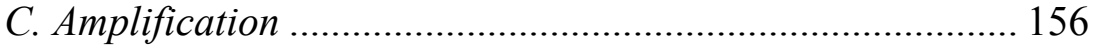

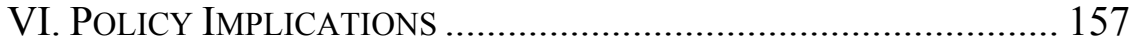

A. Division of Labor: Choosing Between Type 1

and Type 2 Reasoning ..................................................... 157

Textualism vs. Intentionality ....................................... 158

B. Deciding Close Cases ..................................................... 158

C. Guarding Against Prejudice ............................................ 159

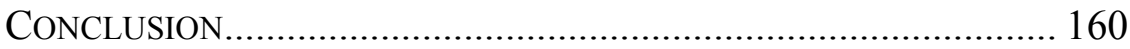

\section{INTRODUCTION}

"Beauty is Truth, [and] Truth Beauty" - John Keats (1795-1821) ${ }^{1}$

Scholars have recognized since the eighteenth century that human thought proceeds through two distinct processes - what psychologists call "Type 1" (intuitive) and "Type 2" (logical). Type 1 usually dominates in

1. John Keats, Ode on a Grecian Urn, in The PoEms of JoHn KeAts 372-73 (Jack Stillinger ed., Harvard Univ. Press 1978) (1820).

2. For a recent book-length account, see generally DANIEL KAHNEMAN, THINKING, FAST AND SLOw (2011). Kahneman provides a useful table comparing the two modes. Id. at 105. The terms were originally coined by Keith Stanovich and Richard West. Id. at 48. 
the arts, with Type 2 playing a supporting role at best. However, Type 1 also hosts the brain's capacity for pattern recognition, making it a reliable guide in fields where truth is defined by logic and experiment. Research in physics and mathematics often consists of extending Type 1 intuitions into Type 2 logical proofs.

The hallmark of Type 1 processes is the mysterious aesthetic emotion that Keats called "beauty." Modern brain scans confirm that the perception of beauty in art and mathematics is located in nearly identical regions of the brain. This makes it natural to ask how legal thought compares to art and mathematics. While legal scholars typically assume the primacy of logic, critics since Justice Holmes ${ }^{3}$ have protested that many cases are actually decided by the unconscious and intuitive methods that Judge Posner calls "practical reasoning."

This Article takes these insights seriously by analyzing legal reasoning and the institutions based on it in explicitly Type 1 terms. This marks a fundamental change from older approaches that try to construct jurisprudence exclusively from Type 2 logic. The shortcomings of the latter approach are particularly evident in the decades-long agenda to find an intellectually coherent middle ground between formalists, who claim that legal texts are completely determinate, and realists, who see judges as entirely unconstrained. While most lawyers agree that such a middle ground exists, we will see that existing philosophy-of-language accounts based on narrowly Type 2 logic can only accommodate it at the cost of introducing ugly, ad hoc assumptions. This Article argues that progress will be better served by acknowledging the existence of Type 1 processes and asking how they enter the law.

3. As Holmes famously declared, "The life of the law has not been logic: it has been experience .... The law ... cannot be dealt with as if it contained only the axioms and corollaries of a book of mathematics." O.W. Holmes JR., THE COMMON LAW 1 (1881). Prof. Hawkins has persuasively argued that the word "experience" denotes subconscious intuition and, conversely, that Holmes saw formalist reasoning as "a vain attempt to systematize intuitively developed law." Brian Hawkins, The Life of the Law: What Holmes Meant, 33 WhitTIER L. REV. 323, 323-76 (2012).

4. Richard A. POSNER, LAW AND Literature: A MisunderstoOd RELATIONSHIP 287 (1988) ("[B] etween the extremes of logical, or scientific, persuasion and emotive persuasion lie a variety of methods for inducing justified true belief that are rational though not rigorous or exact. This is the domain of practical reason."); see also RichARD A. POSNER, HOW JUDGES THINK 9 (2008) (arguing that the existence of judicial discretion "is a consequence of legalism's inability in many cases to decide the outcome (or decide it tolerably....), and the related difficulty, often impossibility, of verifying the correctness of the outcome, whether by its consequences or its logic"). Posner also stated that "legalist tools - including those most hallowed ones of reasoning by analogy and strictly interpreting statutes and constitutions - come up short: The first is empty and the second has, despite appearances, a large discretionary element." Id. at 12. Additionally, he noted that "[1] egalists acknowledge that their methods cannot close the deal every time ... . There are too many vague statutes and even vaguer constitutional provisions, statutory gaps and inconsistencies, professedly discretionary domains, obsolete and conflicting precedents, and factual aporias." $I d$. at 47. 
Similar changes are already underway in the humanities, where many scholars now stress that the subjective sense of beauty causes demonstrable changes in the brain. This immediately implies that realistic theories of text interpretation must consider the reading, aesthetics, and form of texts at least as much as the postmodern fixation on politics and culture. ${ }^{5}$ This Article similarly seeks a biologically accurate understanding of how lawyers write and interpret texts. That said, law poses special problems. The reason is that a successful legal theory, unlike literature, should point to a single best interpretation. This requires that experts reach reliably similar judgments, at least on average, regardless of the culture they were born into. This kind of universality is natural in the sciences: given that there can be only one truth in the physical world, humans' Type 1 intuitions must similarly converge or they would not be useful. We argue that lawyers who spend their lives drafting documents to constrain an uncertain future will develop similarly convergent intuitions in any society where lawyering exists as a discernible activity. The surprise is that the Type 1 emotion of beauty is similarly universal for entirely subjective choices. For example, psychologists have shown that artists in small Japanese villages reliably make the same aesthetic judgments as American Ivy League experts. This implies that lawyers may have similarly aesthetic preferences for some doctrinal choices compared to others.

This Article starts from these basic psychological facts to construct a positive theory of how Type 1 processes enter into legal reasoning, shape the subjective experience of law, and explain why lawyers from widely different backgrounds nevertheless tend to reach closely similar judgments. We then build on these insights to make specific policy recommendations and normative claims. In particular, the existence of universality implies that all lawyers share at least some common Type 1 beliefs regardless of education and life experience. This gives new and much more precise grounds for believing the traditional claim that legal disputes can be decided in ways that are safely insulated from personal or political bias.

We proceed as follows. Section I reviews historic attempts to locate law within the more general problem of text interpretation. Section II reviews what scientists have learned about Type 1 thought processes, including mounting evidence that they provide a reliable guide to truth in such fields as visual art, literature, physics, and mathematics. We also describe evidence for a modest universality whereby experts from widely different cultural and educational backgrounds often reach the same

5. See Paul B. Armstrong, How Literature Plays with the Brain: The Neuroscience OF READING AND ART 55 (2013). 
aesthetic judgments. Section III presents evidence for Type 1 reasoning in law and traces how it enters doctrine to decide cases. Section IV surveys nineteenth century arguments that what we now call Type 1 reasoning should be embraced as a reliable guide to law. It also updates these theories to accommodate the more modest versions of universality that modern science has documented. Finally, it asks how the prevalence of Type 1 thought frames lawyers' everyday experience of practice. Section V asks how legal institutions amplify universality's weak ex ante consensus to generate stable, predictable rules. Section VI extends these arguments to make policy recommendations.

\section{THE LAW-AND-LITERATURE DEBATE}

Since the 1980s, legal scholars debating the determinacy of legal texts have almost always grounded their arguments in literary theory. The resulting law-and-literature movement can be traced to Professor Levinson, who argued that humanities scholars could help lawyers establish a coherent "set of rules" for estimating the "hardness" of meaning against conflicting interpretations. ${ }^{6}$ This was both natural-legal documents are plainly texts - and practical. The advantage, according to Levinson, was that literary theory had long since moved beyond the law's arid debate between legal realists, who stress the "reality of disagreement among equally competent speakers of the native language"7 and formalists "infatuate[ed] . . . with the possibility of a science of criticism." ${ }^{8}$ Despite this, Levinson was not particularly hopeful, concluding with the gloomy assessment that attempts to find meaningful patterns in precedent remain "a supreme act of faith."

Two years later, Professor Dworkin seconded Levinson's claim that literary theory could help scholars escape law's "flat distinction between description and evaluation." 10 But he also warned that these theories could make law less determinate, creating "hard cases" that judges would have to decide "as a question of political theory," although he hoped that judges would choose these theories based on natural "fit" rather than personal politics. ${ }^{11}$ At least in retrospect, Dworkin's decision to invoke the aesthetic

\footnotetext{
6. See Sanford Levinson, Law as Literature, 60 Tex. L. REv. 373, 373-406 (1982).

7. Id. at 379 .

8. Id. at 380 .

9. Id. at $402-03$.

10. Ronald Dworkin, How Law is Like Literature, in A MATTER OF PRINCIPLE 146-77 (1985).

11. See id. at 160-61 ("There is, of course, no algorithm for deciding whether a particular interpretation sufficiently fits that history not to be ruled out ... as a question of political theory."). Dworkin also stated that "any particular judge's theory of fit will often fail to produce a unique interpretation." Id. at 161.
} 
concept of "fit" was an early hint that Type 1 reasoning could limit discretion.

At this point, literary critic Stanley Fish entered the debate. His most lasting contribution was to frame the problem in formally Type 2 terms as "a few basic questions in the philosophy of language." 12 He then added that an "interpretative community" could narrow the list of permissible meanings. ${ }^{13}$ However, this superficially attractive claim is empirically doubtful $1^{14}$ and, in any case, fails to supply the middle ground that Levinson and Dworkin had sought. On the one hand, it implied that an unelected elite would decide for everyone, a possibility that Levinson had rejected. ${ }^{15}$ On the other hand, no one could say exactly how much narrowing would occur since this necessarily depended on who joined the community. This gap was particularly painful since the existence of just one conflicting interpretation could leave judges unconstrained.

Watching the argument play out, Judge Posner protested that the lawand-literature analogy had been misguided all along. ${ }^{16}$ Literature, he said, was aesthetic and profited from ambiguity. But law was different, and much more like everyday speech: "If a message is garbled ... you try to glean from everything you know about [the sender] and the circumstances of the failed message what he might have meant ... the correct analysis is an intentionalist one." ${ }^{\prime 17}$ By comparison, the kinds of clever interpretive ambiguities that Fish and the legal realists celebrated were more "obtuse ... than ingenious." 18

Fish shot back that Posner's attempt to create a special subcategory for legal texts changed nothing: after all, philosophy-of-language

12. Stanley Fish, Doing What Comes Naturally: Change, Rhetoric, AND the Practice OF THEORY IN LITERARY AND LEGAL STUDIES 1 (1989).

13. See id. at $143-60$.

14. Fish is, of course, trivially correct if we choose to identify his "interpretive community" with the country's 1.2 million practicing lawyers. Attorneys in the U.S., WIKIPEDIA, https:/en.wikipedia. org/wiki/Attorneys_in_the_United_States [https://perma.cc/R95G-LTGA]. However, this number is far too large to place any useful limit on the number of viewpoints. Fish would presumably reply that professional hierarchies and social structures play a much bigger role in defining which opinions are respectable. But there is almost no empirical evidence on how much narrowing actually happens, suggesting that the mechanism might well be too weak to matter.

15. See Levinson, supra note 6, at 384 (While one can appeal to "Kuhnian communities" of shared conventions, we should be "acutely aware of the contingency of such judgements."). Fish himself seemed to welcome such power, arguing that literary theory "might play a role in altering the way in which the legal world is constructed by altering the way in which legal actors conceive of their activities." FISH, supra note 12, at 308.

16. See POSNER, LAW AND LitERATURE, supra note 4, at 240.

17. Id.

18. Id. at 242. Posner's specific ire was directed to a hypothetical argument that the Constitution did not literally require presidents to be 35 years old, but only have "the maturity and station in life of an average 35 year old." Id. 
arguments applied to all texts whatsoever. ${ }^{19}$ Formally, this bit of Type 2 logic was irreproachable. All the same, Posner had a point. While philosophy-of-language arguments showed that variant interpretations were possible, they said nothing at all about which ones were likely. This created a deep conflict with the nearly universal perception that some legal and also literary interpretations are enormously better than others. ${ }^{20}$ This mattered, Posner explained, since narrowing the analysis to "better" readings could usefully "box in" judges' discretion even when some ambiguity remained. ${ }^{21}$

Thirty years later, legal scholars continue to wrestle with essentially the same arguments. ${ }^{22}$ In the meantime, literary theory has begun moving beyond narrow philosophy-of-language approaches to consider empirical evidence that humans' response to reading produces measurable changes in the brain. ${ }^{23}$ This suggests that texts matter, rebutting accusations that literature is merely the "constructed handmaiden of sociopolitical power." 24 But in that case, it is also reasonable to ask whether Type 1 processes favor some textual interpretations compared to others. Remarkably, recent science strongly supports this conjecture.

\section{THE SCIENCE}

Critics have cited the subjective emotion of beauty as evidence for an underlying unity in how humans understand painting, music, literature, and the other "sister arts" since the eighteenth century. ${ }^{25}$ However, the

19. FISH, supra note 12, at 303-04 (rejecting Posner's distinction because interpretation is "indistinguishable from what you think, in advance, the text is for and also from what you take to be your relation to it.") (emphasis in original).

20. ARMSTRONG, supra note 5, at 9 ("The fact that interpreters may have interesting, productive disputes about textual meaning does not prevent agreement among practitioners whose authority has been accredited in various ways that some interpretations are less credible than others...."); Levinson, supra note 6, at 384 (In law, not even "radical critics defend the position that any interpretation is as good as any other.").

21. POSNER, HOW JUDGES THINK, supra note 4, at 13 (explaining that even pragmatist judges are "boxed in, as other judges are, by ... [factors including] a due regard for the integrity of the written word in contracts and statutes").

22. For two recent contributions, see, e.g., Mark Kingwell, Let's Ask Again: Is the Law Like Literature, 6 YAlE J.L. \& Human. 317, 317-52 (1994); James Seaton, Law and Literature: Works, Theory, and Criticism, 11 YALE J.L. \& HUMAN. 479, 479-07 (1999).

23. See, e.g., Nancy Easterlin, Review: How Literature Plays With the Brain, 39 PHILOSOPHY \& LITERATURE 1, 267-70 (2015).

24. Id. at 267.

25. See G. Gabrielle Starr, Feeling Beauty: The Neuroscience of Aesthetic EXPERIENCE 4 (2013) ("Most theories of the Sister Arts have focused resolutely and explicitly on the subjective dimensions of response."). Starr also stated that "the idea that there is a single autonomous domain in which we might discuss or reason about the visual arts, literature, music, imagination, beauty, the sublime, or even the vulgarly awful is an invention of the eighteenth century." Id. at xiixiii. 
same perception also occurs in objective subjects like mathematics ${ }^{26}$ and physics ${ }^{27}$ along with a wide variety of mundane tasks. ${ }^{28}$ Probably the most instructive example is chess, where masters learn to use Type 1 reasoning to identify the most important and creative possibilities with a single glance. $^{29}$ Such examples argue that unconscious intuition is not just aesthetic, but also plays a key role in practical problem-solving.

The outlines of what we now call Type 1 thought were already clear by 1821. That year, the poet and political radical Percy Bysshe Shelley wrote a celebrated essay contrasting "reason," which he argued was limited to "algebraical relations" between known thoughts, ${ }^{30}$ with a second faculty of "imagination" that was alone capable of making other thoughts from existing ones, ${ }^{31}$ and deploying them "according to a certain rhythm and order which may be called the beautiful and the good." 32 Anticipating Freud by half a century, he went on to link imagination with what we now call the unconscious. ${ }^{33}$ Less convincingly, Shelley also anticipated Jung by claiming that aesthetic insights were universal, originating in the mind of God. ${ }^{34}$

Two centuries of scientific research have refined and formalized these insights. Today, the characteristic Type 1 operations specialize in pattern recognition and the mental processes variously called "judgment,"

26. Bertrand Russell, The Study of Mathematics, in MYsTICISM AND LOGIC AND OTHER EsSAYS 60 (3d ed. 1976) (“[M]athematics, rightly viewed, possesses not only truth, but supreme beauty."); see also Vicky Neal, Mathematics is Beautiful (No, Really), The CONVERSATION (Feb. 17, 2017), http://theconversation.com/mathematics-is-beautiful-no-really-72921[https://perma.cc/GR8N-E258].

27. P.A.M. Dirac, The Relation Between Mathematics and Physics, 59 Proc. R. Soc. EDINBURGH 1, 122-29 (1939) (arguing that workers seeking the fundamental laws of nature "should strive mainly for mathematical beauty"), https://pdfs.semanticscholar.org/e69a/466c2576a4de2e77dd 7bcb77c1f2ad5b2d6d.pdf [https://perma.cc/JC7R-2MQZ]. See generally FranK WiLCZEK, A BeAutiful Question: Finding NATURE's DeEP DESIGn (2015) (documenting use of "beautiful thoughts" in constructing scientific theories from Pythagoras to particle physics). Significantly, physicists' subjective experience of beauty is classically Type 1: in Dirac's phrase, it "cannot be defined, any more than beauty in art can be defined[.]" Dirac, supra, at 122-29.

28. KAHNEMAN, supra note 2, at 236-37 (Firefighters can intuit exactly when a house will collapse without knowing how they do it.).

29. See id. at 238-39.

30. Percy Bysshe Shelley, A Defence of Poetry or Remarks Suggested by an Essay Entitled "The Four Ages of Poetry," in SHELley's POETRY AND PROSE 480 (1977). The essay first appeared posthumously in PERCY BYSSHE SHELlEy, ESSAYS, LETTERS FROM ABROAD, TRANSLATIONS AND FRAGMENTS (1840).

31. Shelley, supra note 30, at 480; see also id. at 503 (Imagination allows humans to create "new materials of knowledge, and power, and pleasure.").

32. $I d$. at 503 .

33. Id. at 506 (The poetic imagination "differs from logic, that it is not subject to the controul of the active powers of the mind, and that its birth and recurrence have no necessary connexion with the consciousness or will.").

34. Id. at 485 (Aesthetics are defined "as existing in the mind of the creator, which is itself the image of all other minds."). 
"intuition," and "aesthetics." "35 These are very unlike the brain's alternative Type 2 thought process, variously called "reason" and "logic." 36 The hallmark of the latter is that it can be articulated, reduced to unambiguous instructions and, as Alan Turing predicted, implemented by machines. ${ }^{37}$ Crucially, much of the best evidence remains subjective: Type 1 and Type 2 methods simply feel different. For example, aesthetic reasoning is routinely described as unconscious, automatic, and having little sense of effort or control. ${ }^{38}$ This means that even when we recognize a pattern, we often cannot say why. Sometimes the mind's logical, Type 2 methods can replicate the insight, sometimes they can't. ${ }^{39}$

The next Section reviews what scientists have learned about the nature of Type 1 judgments, focusing on the surprising result that artists from different societies often make the same aesthetic judgments, regardless of the cultures that they were born into.

\section{A. Type Intuition: Aesthetics and Fast Thinking}

Professor Armstrong argues that Type 1 reasoning enters reading through the "recognition of patterns." both upward (by assembling details into overall patterns) and downward (by using the overall pattern to make sense of details). ${ }^{41}$ From this standpoint, legal reasoning — which consists almost entirely of finding and

35. See generally Carlos E. Perez, Artificial Intuition: The Improbable DeEP Learning REVOLUTION (2018).

36. Id. at 96.

37. See Turing Machine, WIKIPEDIA, https://en.wikipedia.org/wiki/Turing_machine [https:// perma.cc/PH3J-H985]. Turing's logic was nicely anticipated by the poet W.B. Yeats, who noticed after refusing a political debate

that all the arguments which had occurred to me earlier were said by somebody or other.

Logic is a machine; one can leave it to itself, and unhelped it will force those present to

exhaust the subject. The fool is as likely as the sage to speak the appropriate answer to any

assertion. If an argument is forgotten, someone will go home miserable. You throw your

money on the table, and you receive so much change.

BARRY SHIELS, W.B. YeATS AND WORLD LiterATURE: THE SubJeCt OF POETRY 166 (2015) (quoting Yeats' 1908 journal entry).

38. See KAHNEMAN, supra note 2, at 20.

39. Remarkably, the dichotomy between logic and pattern recognition also applies to machines. Computers built around human-supplied Type 2 logic are wonderful at arithmetic but do a terrible job of recognizing patterns. Conversely, "neural network" architectures that learn by interacting with the environment have the opposite problem: they are good at recognizing patterns but incapable of long division. PEREZ, supra note 35, at 96.

40. ARMSTRONG, supra note 5 , at 58 .

41. Id. at 54-55. Armstrong provides a detailed description of this dynamic, which he calls the "hermeneutic spiral." Id. The key insight is that interpretation requires "the reciprocal construction of an overall order and its constituent parts, the overarching arrangement making sense of the details by their relation to one another, even as their configuration only emerges as the parts fit together." $I d$. at 54. This leads to characteristic "to-and-fro adjustments, between the details of the work and the configurations one expects (and may or may not find)." Id. at 55. 
comparing patterns across different levels of text $\mathrm{t}^{42}$ - is just one example of how the brain uses its exquisitely refined pattern-spotting circuits to make sense of the world.

\section{Brain Imaging}

We have already said that the perception of beauty has been reported not just for art, but also for mathematics, physics, and a wide variety of practical tasks. The advent of brain imaging has given this subjective claim a physical basis in the brain. So far, most of this work has concentrated on mapping regions that respond to visual art. $^{43}$ However, images of the brain's aesthetic responses to music ${ }^{44}$ and mathematics ${ }^{45}$ turn out to be closely similar.

The more general lesson is that the images hint-however coarsely ${ }^{46}$ - at how thought can be identified with physical structures in the brain. This viewpoint is particularly natural for Type 1 reasoning, which can be convincingly described as a process of "wiring" neurons together into "circuits" that have been optimized to detect specific patterns. Whereas most sensations are simply noise, ${ }^{47}$ coherent patterns stimulate the brain's pleasure centers by confirming existing neural connections and forming new ones. ${ }^{48}$ This has obvious survival value in a world where it is important both to exploit previously-discovered patterns and to consider new ones.

42. See infra Section IV.

43. STARR, supra note 25, at 34 ("The first neuroscientists interested in aesthetics were primarily concerned with visual art, for vision, as the sense most accessible to behavioral evaluation, has been the most robustly understood area of perception.").

44. S.E. Trehub, Human Processing Predispositions and Musical Universals, in THE ORIGINS OF MUSIC 427-28 (2000); STARR, supra note 25, at 48; Tomohiro Ishizu \& Semir Zeki, Toward a Brain-Based Theory of Beauty, 6 PLOS ONE 7, 42 (2011) (Aesthetic reactions to music and painting produce effects in areas of the brain that are involved with emotion processing, although the data "do not preclude subtle differences in the timing of neural activity.").

45. S. Zeki, J.P. Romaya, D.M.T. Benincasa \& M.F. Atiyah, The Experience of Mathematical Beauty and Its Neural Correlates, FronTIERS IN HUMAN NeUROSCIENCE, Feb. 2014, at 1, 10 (finding a "very close" though "not perfect" correspondence for mathematical, musical, and visual beauty in the same regions of the brain).

46. For the foreseeable future, the images are too crude to identify individual neurons, or resolve the millisecond-by-millisecond changes that drive brain function. ARMSTRONG, supra note 5, at 4; see also Keith Sawyer, Brain Imaging: What Good Is It? Brain Imaging Promises Much, but Offers Little (At Least, so Far), PSYCHOL. TODAY (Oct. 21, 2013), https://www.psychologytoday.com/blog/ zig-zag/201310/brain-imaging-what-good-is-it [https://perma.cc/EUV2-AAND].

47. ARMSTRONG, supra note 5, at 15 ("Harmony and dissonance in art are defined not only by each other but also by their opposition to a third concept—noise .... The human brain's capacities for synthesis are not unlimited.... Some stimuli simply are not noticed. If they are perceived but cannot be processed, they are noise.").

48. Id. at 50 ("There is interesting experimental evidence that the making and breaking of neuronal connections stimulates the expression of neurotransmitters strongly associated with pleasure in ways that no doubt affect aesthetic experiences."). 
The brain's other characteristic strategy is to recycle established circuits for new tasks. ${ }^{49}$ But in that case, reasoning for the new purpose remains hostage to maintaining the original function - a brain that uses the same circuits for tort law and crossing the street will stop improving the former when it compromises safety. This suggests that we may sometimes find ourselves locked into certain perceptions, although the brain often finds workarounds. ${ }^{50}$

\section{Neural Networks}

Finally, our understanding of Type 1 pattern recognition has been deeply influenced by artificial intelligence research. While neural network computers do not claim to duplicate actual brain architectures, they nevertheless show what happens when large numbers of neuron-like (multiple input, non-linear response) circuits are wired together to find patterns. ${ }^{51}$ Unlike traditional approaches based on Type 2 logic supplied by humans, neural networks learn by trial-and-error, constantly rewiring themselves to make pattern detection more efficient. ${ }^{52}$ But while they sometimes make predictions that no human can duplicate, their reasoning often cannot be articulated or even understood by us. Indeed, some make predictions that no human can duplicate. ${ }^{53}$ What makes this strange is that every neural network can be formally reduced to a set of linear algebra

49. Reading short stories activates the same regions that the reader would use if they were performing, imagining, or observing the protagonist's actions in real life. Nicole K. Speer, Jeremy R. Reynolds, Khena M. Swallow \& Jeffrey M. Zacks, Reading Stories Activates Neural Representations of Visual and Motor Experiences, 20 PSYCHOL. SCI. 989 (2009).

50. ARMSTRONG, supra note 5, at 36-37 (Girl whose normal left brain region for recognizing letters had been damaged was able to develop the mirror image right brain region for the same purpose.).

51. PEREZ, supra note 35. Readers can build intuition about how neural networks work by reading Anderson's lucid, albeit rigorous account of the so-called "Perceptron" machines built in the 1950s. JAMES A. ANDERSON, AN INTROduction to NeURAl Networks (1995). The basic architecture featured three types of element: Sensors (S) which detect signals from the external world, Associative Cells (A) that are wired to multiple sensors to detect simple patterns (e.g. lines, triangles) and Relational Cells (R) that are wired to multiple A cells to detect higher-order patterns like houses or fire trucks. Crucially, the A and R cells exhibit "threshold," i.e. only fire when incoming signals exceed some predetermined value. The machine then evolves to maximize the probability that one and only one R cell will fire when the desired pattern appears. This is done by rewiring the connections between the A and R cells each time detection fails. Specifically, A cells that sent out a positive signal produce a higher output the next time, while A cells that sent out a negative signal have their strength reduced. This makes it more likely that the relevant $\mathrm{R}$ cell will guess right next time. Id. at 220 . The same basic architecture can also be modified to solve more abstract problems, for example creating categories that parsimoniously distinguish different types of events. Id. at 209-38.

52. See Fabio Ciucci, AI and Deep Learning, Simply Explained, KD NugGETS (July 2017) (Neural network program trained on data from 700,000 patients can predict schizophrenia onset better than humans.), https://www.kdnuggets.com/2017/07/ai-deep-learning-explained-simply.html [https:// perma.cc/2EAV-BSLC].

53. Id. 
equations. ${ }^{54}$ Despite its formal clarity, the mathematics is much too complicated for our Type 2 selves to understand. ${ }^{55}$

\section{B. Universality}

Philosophy-of-language arguments have difficulty explaining why one interpretation should be better than any other. An improved theory must add assumptions that break this symmetry. Fish's suggestion of an elite interpretive community is one (unpalatable) way to do this. This Article starts from different evidence showing that certain judgments are universal, i.e. that human experts often make the same Type 1 choices no matter what culture they were born into. Crucially, this universality implies that experts from any one country share common ground no matter how much they disagree about culture and politics.

\section{Objective Problems}

The idea that Type 1 perceptions in fields like physics or mathematics are universal seems entirely reasonable. Type 1 methods are, after all, optimized to spot patterns. In fields where the physical world defines a single truth, any sense of beauty which reliably points to that truth must similarly converge on a unique pattern. For example, we would expect aliens who evolved on other planets to arrive at much the same understanding of physics that we have. ${ }^{56}$ Probably the best-studied example of how external reality forces convergence comes from studying how humans from widely separate cultures interpret random ink blots ("Rorschach patterns") as people, animals, or insects. Of the thirteen most popular responses found in North America, nine appear to be universal, meaning that they elicit similar responses at similar rates across Europe, ${ }^{57}$

54. Id. (Machine learning "computations are visible, but too many to make a human-readable summary."); Sean Captain, We Don't Always Know What AI is Thinking-And That Can Be Scary, FAST COMPANY (Nov. 15, 2016) (quoting IBM's Cognitive Computing Officer: "It's not clear even from a technical perspective that every aspect of AI algorithms can be understood by humans"), https:/www.fastcompany.com/3064368/we-dont-always-know-what-ai-is-thinking-and-that-can-bescary [https://perma.cc/VS3B-685E].

55. See id.

56. See, e.g., Richard P. Feynman, Fernando B. Moringo \& William G. Wagner, The FEYNMAN LECTURES ON GRAVITATION 2 (1995) et passim (arguing that Venusian physicists would eventually discover gravity even if clouds made the stars invisible).

57. Anne Andronikov-Sanglade, Use of the Rorschach Comprehensive System in Europe: State of the Art, in HANDBOOK OF CROSS-Cultural AND Multicultural PERSONALiTy AssESSMENTS 338-39 (2000) (reporting French data); see Eugenia V. Vinet, The Rorschach Comprehensive System in Iberoamerica, in HANDBOOK OF CROSS-Cultural AND MulticulturAL PERSONALiTy ASSESSMENTS 347-49 (2000) (reporting data for Spain and Portugal). 
Japan, ${ }^{58}$ and Latin America. ${ }^{59}$ As Professor Weiner remarks, this universality follows from the fact that alternative interpretations would require "a substantial distortion or misrepresentation." ${ }^{\circ 0}$ In these cases, at least, "[ $\mathrm{t}]$ he boundaries between realistic and unrealistic perception are universal and not culture bound."

\section{Aesthetic Convergence}

The harder question is whether purely aesthetic responses can be similarly universal. Psychologists first proposed experiments to probe how humans make aesthetic judgments in the 1870s. ${ }^{62}$ However, early researchers soon reported that average people do not share aesthetic judgments across cultures. ${ }^{63}$ This finding seems to have discouraged further research until Professor Irvin L. Child took a second look in the 1960 s. ${ }^{64}$ While Child confirmed that lay opinion does indeed depend on culture, this was not true for experts.

Child's method depended on asking native artists to compare similar paintings. In each case, American experts had overwhelmingly agreed that one design was aesthetically superior to the other. ${ }^{65}$ In his most famous study, Child showed pairs of both abstract and representational paintings to thirty-six Japanese potters in small rural villages. They agreed with American Ivy League experts $63 \%$ of the time. Significantly, the odds of this happening by chance were less than one percent ${ }^{66}$ By comparison, the same Ivy League experts' chances of agreeing with a Connecticut high school student were just $47 \%$-indistinguishable from a simple coin toss. ${ }^{67}$ Child and his coauthors went on to document similar results for

58. Irving B. Weiner, Principles of Rorschach Interpretation 52 (2d ed. 2003) (reporting Japanese data).

59. Vinet, supra note 57, at 350-52 (reporting data for Chile, Brazil, and Venezuela).

60. WEINER, supra note 58 , at 53 .

61. Id.

62. Gustav Fechner proposed, but did not implement, an experimental agenda to explore the psychology of aesthetics in the 1870 s. See Irvin L. Child \& Rosaline S. Schwartz, Exposure to Better and Poorer Art, 2 J. AEsTHETIC EDUC. 111, 118 (1968).

63. Irvin L. Child \& Leon Siroto, BaKwele and American Esthetic Evaluations Compared, 4 ETHNOLOGY 349, 350 (1965).

64. Id. at 349 (collecting pre-Sixties literature and concluding that psychologists had tried experimental tests of aesthetic relativity "to an astonishingly small degree"). Child taught his introductory psychology class to me and several hundred other Yale freshmen in 1975.

65. Id. at 350. Child took great pains to test experts who had never been exposed to Western culture-a process much easier in the 1960s than it is today.

66. Sumiko Iwao \& Irvin L. Child, Comparison of Esthetic Judgments by American Experts and by Japanese Potters, 68 J. SOC. PSYCHOL. 27, 30 (1966).

67. Id. at 32 . 
isolated communities in Japan ${ }^{68}$ Fiji,${ }^{69}$ West Africa,${ }^{70}$ Ecuador, Peru, and Puerto Rico. ${ }^{71}$ Subsequent studies have generally confirmed these findings ${ }^{72}$ but added little beyond trying to localize universality in particular parts of the image. ${ }^{73}$

Child's universality only occurs in specific circumstances. First, it is limited to humans ("experts") who have spent large parts of their lives making aesthetic choices. Second, the effect is modest, just $10 \%$ more than a coin toss. This makes it nearly invisible in everyday life unless and until humans organize surveys to look for it. Third, Child's method uses similar images and therefore makes no claim to large choices, say that a Picasso painting has more aesthetic value than an African folk mask.

\section{Origins}

It is natural to ask what causes universality. Given that the effect only applies to experts, learning must play a role. This immediately rules out explanations in which evolution has hardwired aesthetic preferences directly into the brain. Instead, Child argued that artists learn by contemplation, independently discovering "similar facts about the adequacy of particular works for satisfying aesthetic interests." 74

68. A subsequent study tested Japanese subjects from seven additional crafts including flower arranging, tea ceremony, and textile dying. Sumiko Iwao, Irvin L. Child \& Miguel Garcia, Further Evidence of Agreement Between Japanese and American Esthetic Evaluations, 18 J. Soc. PSYCHOL. 11,15 (1969).

69. C.S. Ford, E. Terry Prothro \& Irvin L. Child, Some Transcultural Comparisons of Esthetic Judgment, 68 J. Soc. PSYCHOL. 19, 26 (1966) (Six subjects agreed with American experts $78 \%$ of the time; significant at the one percent level.). The authors also found a similar trend among four craftsmen from the Greek Islands, but this was statistically insignificant. Id. at 23-25.

70. Child \& Siroto, supra note 63, at 351. The agreement on African masks was significant at the one percent level.

71. See Irvin L. Child, The Psychological Meaning of Aesthetic Judgments, in VISUAL ARTS RESEARCH 53 (1983) (describing three small Latin American studies).

72. Julian P. Renoult, The Evolution of Aesthetics: A Review of Models, in AESTHETICS AND Neuroscience: SCIENTIFIC AND ARTiSTiC PerspeCtives 282 (Zoï Kapoula \& Marine Vernet eds., 2016) ("Many subsequent studies have concurred with this view that aesthetic preferences and beauty are, at least in part, universal and innate."). One recent study shows that art students are much more likely than lay audiences to choose abstract paintings by professional painters over similar works by children and animals. Though seemingly unaware of Child's work, their result neatly reproduces his strong distinction between experts and lay audiences. See Angelina Hawley-Dolan \& Ellen Winner, Seeing the Mind Behind the Art: People Can Distinguish Abstract Expressionist Paintings From Highly Similar Paintings by Children, Chimps, Monkeys, and Elephants, 22 PSYCHOL. SCI. 435, 440 (2011).

73. The strategy is particularly tempting in an era when computers make it easy to decompose images into mathematically precise "Fourier" and "Power Spectra" components. See, e.g., Renoult, supra note 72, at 282; Wilfried van Damme, Universality and Cultural Particularity in Visual Aesthetics, in BeIng Humans: ANTHRopological Universality and PARTICUlarity in TRANSDISCIPLINARY PERSPECTIVES 258 (Neil Roughley ed., 2000).

74. Child \& Siroto, supra note 63, at 33. 
However, this still left the question of what generates these underlying "aesthetic interests" to begin with. This was probably unanswerable in the 1960s. Today, however, we know that the brain's pleasure centers reward us for forming new neural connections and using old ones. ${ }^{75}$ In this view, art is a form of play designed to question our established views of the world and try out new ones.

For now at least, Child's hypothesis is not the only possibility. Aesthetic convergence could also be driven by a self-selection effect in which certain personality types preferentially become potters. In principle, this can be checked by testing how peoples' aesthetic responses change before and after they become experts, although little work has been done in this area. ${ }^{76}$

\section{Education and Socialization}

Child showed that students could be taught to improve their test scores by simulating taste, i.e. guessing what experts would say. ${ }^{77}$ However, scores rose faster when instructors focused on showing students how to appreciate art and asked for sincere (unsimulated) responses. ${ }^{78}$ Significantly, Child taught this aesthetic sense using the traditional methods of art criticism, i.e. giving students Type 1, non-algorithmic hints about what to look for. ${ }^{79}$

Child's universality research was limited to art. However, anecdotal evidence suggests that the sense of beauty in physics similarly flows from prolonged contemplation without any need for special education or indoctrination. As the physicist P.A.M. Dirac remarked, people who study mathematics "usually have no trouble in appreciating [beauty]." 80

75. See ARMSTRONG, supra note 5, at 48-49.

76. Child and Schwartz did perform a small-scale experiment which asked nineteen students to examine paired images for eight hours apiece. While they found no evidence of learning, this was not surprising. Child's artists had invested orders of magnitude more time making aesthetic choices. Child \& Schwartz, supra note 62.

77. Id. at 112 (School children who had been told which images experts preferred could be taught to distinguish "fairly well" which art was considered "better.").

78. Irvin L. Child \& Rosaline S. Schwartz, Exploring the Teaching of Art Values, 1 J. AESTHETIC EDUC. 41 (1966).

79. Child found that students made "impressive" progress when he showed them seven principles, each illustrated with pairs that did and did not follow the suggested advice. Id. at 51. Child's principles were selectivity, organization, consistency, variety, aliveness, use of decoration, and appropriate use of elements. $I d$. at 50-51. These cryptic labels were explained through detailed-but far from algorithmic - definitions which demand further judgment from the reader. For example, Child defined "Use of Decoration" as follows: "Good decoration must suit the object. It must not 'fight' with the object as a whole in line, color, textures, shapes, or forms. Good decoration must seem an essential part of the object or work of art and not look 'stuck on' as an afterthought. Good decoration does not ask attention for itself but permits the entire object or work of art to remain most important." Id.

80. Dirac, supra note 27, at 122-23. Mathematician Vicki Neal similarly stresses the central importance of contemplation in learning to appreciate beauty: 


\section{TYPE 1 THINKING IN LAW}

It is clear that Type 1 insights play a significant role in fields ranging from the visual arts to mathematics. However, the relative importance of Type 1 and Type 2 processes varies dramatically by discipline. This makes it natural to see law as an intermediate case along a continuum between art (principally Type 1) to science (mostly Type 2). This Section collects evidence for Type 1 reasoning in law and traces the specific mechanisms that let it decide particular cases. ${ }^{81}$

\section{A. The Subjective Experience of Law}

Legal realism's most notorious failing is that it ignores how lawyers actually practice and experience law. ${ }^{82}$ Yet subjective experience was historically the first and most important clue that common brain functions were at work in fields from painting to physics. This makes it natural to look for similar evidence of Type 1 thinking in lawyering's most basic and defining function: writing.

\section{Writing}

Non-legal writing is already deeply entangled with Type 1 thought. This is evident from, among other things, the fact that finding the right words is largely unconscious, brings pleasure, and is almost never

I cannot find a piece of mathematics beautiful unless I first understand it properly - and that means it can take a while for me to appreciate the aesthetic qualities.

I don't think this unique to mathematics. There are pieces of music, buildings, pieces of visual art where I have not at first appreciated their beauty or elegance - and it is only by persevering, by grappling with the ideas, that I have come to perceive the beauty.

For me, one of the joys of teaching undergraduates is watching them develop their own appreciation of the beauty of mathematics.

Neal, supra note 26.

81. Brain imaging researchers have yet to investigate legal reasoning. However, the relevant techniques are being developed, most notably in experiments that image subjects' brains in real time as they proceed through short stories. Speer, Reynolds, Swallow \& Zacks, supra note 49. The additional difficulty for law is that asking subjects to make aesthetic choices for concepts like "nonobviousness" requires so much education that they could be inadvertently socialized to give particular answers. One workaround would be to look for universality in self-contained documents like contracts.

82. As Prof. Solum remarks,

[F]rom a perspective internal to the law, the claim that judging is politics all the way down seems absurd, because it fails to account for the phenomenology of judging. Judges, lawyers, and legal scholars do not experience legal decisionmaking as the exercise of discretion based on politics. This point is actually common ground between legal scholars as diverse as Professor Ronald Dworkin, who believed that there was a legally correct outcome in every dispute, and Professor Duncan Kennedy, who defends the view that law is deeply political.

Lawrence B. Solum, The Positive Foundations of Formalism: False Necessity and American Legal Realism, 127 HARV. L. REV. 2464, 2473-74 (2014) (book review). 
reducible to Type 2 algorithms. That said, we seldom stop to realize just how much work Type 1 processes do. Consider this deceptively simple phrase: "A lovely little old rectangular green French silver whittling knife." ${ }^{83}$ Move a single word and you immediately see that something has gone badly wrong. Yet no one ever taught you an explicit Type 2 rule, and figuring it out is tedious ${ }^{84}$ - so tedious in fact that you begin to wonder how the mind manages to write whole chapters and books. Sometimes this process is purely aesthetic. But it also extends to knowing one's audience and how best to communicate.

\section{Legal Writing}

It is difficult to generalize about how writing's Type 1 content changes when the focus shifts to law. On the one hand, legal documents can be highly algorithmic, most notably in architecting elaborately interlocking definitions and borrowed terms of art. At the same time, they also pose Type 1 problems that lay writing does not. The characteristic lawyering activity is writing rules - for example, legislation, bilateral contracts, and court opinions - that will be interpreted by strangers to decide disputes that are only imperfectly anticipated. While there are better and worse ways to do this, they all depend on reducing massive amounts of life experience to Type 1 insights. But once lawyers learn to write, it is only natural that their brains will commandeer the same circuits to interpret what other lawyers mean. Like Child's potters, the artist becomes the critic. Finally, the circle closes with lawyers recycling their interpretive experience to improve their drafting.

All of this makes lawyers different from the average educated layman. For us, writing is an installment in what Dworkin saw as an endless chain of documents. ${ }^{85}$ It is not enough to memorialize the present; we must also consider how our words could change the interpretation of earlier documents and facilitate accidental or deliberate misunderstanding in the future. ${ }^{86}$

83. Mark Forsyth, The Elements of Eloquence: Secrets of the Perfect Turn of PHRASE (2013).

84. English adjective/noun combinations are invariably ordered opinion-size-age-shape-colororigin-material-purpose-noun. $I d$.

85. See Dworkin, supra note 10, at 158-62.

86. The depth of these professional instincts is most visible when lawyers collaborate with educated lay people. For the past few years I have worked with academic biologists to screen proposed experiments against so-called "ethical, legal, and social implications." Given that our opinions are preserved with an eye to publication, the overall purpose closely resembles a common law court. Yet my lay colleagues seldom see this. Some offer explanations that "prove too much" by facially invalidating large swathes of federal law, or else framing rules that would allow almost any future experiment to go forward. Others give opaque explanations that say almost nothing about what the panel would accept next time. And still others propose fact tests that would be difficult or impossible 


\section{Universality}

We have argued that scientific intuitions converge because there is only one physical world. We cannot know whether there is some similarly uniquely best way to write legal documents. But if there is, there cannot be many, and we should expect practitioners to converge on similar lessons in any society where "lawyering" is a discernible activity. In the modern world this arguably includes every nation on earth. ${ }^{87}$

The deeper question is whether universality goes beyond these shared experiences. Child's work suggests that we should expect aesthetic intuition to operate even when the experience of lawyering teaches no life lessons at all. The joy which many formalists take in verbal gymnastics points strongly in this direction. ${ }^{88}$

\section{Normative Implications}

The existence of universality across countries necessarily implies that lawyers within any one country share common ground about how to interpret legal documents. Furthermore, this ground must exist despite the deep conflicts over values and goals that all societies face. This makes any standards based on this common ground completely democratic, at least if we assume that laypeople would agree with the experts given sufficient time and study.

This normative argument is sufficiently important that we should worry about possible loopholes. The first is empirical. Pending further research, universality could still turn out to be a selection effect, i.e. that legal careers attract people whose values are systematically different from average humans. In that case, agreed standards among lawyers would not represent the broader society after all. Second, assuming that universality is learned, its lessons cannot be broader than the experience of lawyering

to implement in practice. My point is not that I handle these issues better than my colleagues, though I think I do. Rather, it is that they do not see these pitfalls in the first place.

87. But see James Pearson, North Korea's Only Foreign-Founded Law Firm Suspends Operations, REUTERS (July 31, 2016), https://www.reuters.com/article/us-northkorea-lawyer/northkoreas-only-foreign-founded-law-firm-suspends-operations-idUSKCN10C1A1 [https:/perma.cc/ K6PE-J9DS] (reporting that "most" of North Korea's 8,000 lawyers work for the state).

88. Consider, for example, Federal Circuit Chief Judge Helen Nies' argument that the tests for patent law's "non-obviousness" and "substantiality" requirements should be identical. Roton Barrier, Inc. v. Stanley Works, 79 F.3d 1112, 1128 (Fed. Cir. 1996) (Nies, J., concurring). This made little sense from a policy or statutory interpretation perspective, since legal standards that address distinct economic problems should normally be independent of one another. See Ted O'Donoghue, Suzanne Scotchmer \& Jacques-François Thisse, Patent Breadth, Patent Life, and the Pace of Technological Progress, 7 J. OF ECONS. AND MGMT. STRATEGY 1 (1998) (analyzing optimal pairings of "nonobviousness" and "substantiality" standards for different industries). But it did let Nies argue that "[a] substitution in the patented invention cannot be both nonobvious and insubstantial." Roton Barrier, 79 F.3d at 1128 . Here at least, the pleasure of an attractive syllogism seems to have outweighed all other considerations. 
itself. This probably includes a bias toward focusing on the rights and goals of individuals. This could sometimes slant legal reasoning toward, say, capitalist values compared to socialist ones.

\section{B. Mechanics: Finding Alternative Patterns}

The question remains just how Type 1 intuition enters legal reasoning to decide cases. Unlike most of the existing literature, ${ }^{89}$ we decline the (likely impossible) task of reducing legal judgment to completely determinate, Type 2 rules. This Section emphasizes how legal research uses Type 1 methods to find new patterns within legal texts.

Suppose that you represent a client and that your opponent has cited some rule that establishes liability. In the physical world there can only be one truth, ensuring that every pattern must be consistent with every other pattern. Legal doctrine, on the other hand, is assembled piecemeal by many hands over time. This implies that patterns can and often will be inconsistent. The advocate's job is to find a pattern that favors her client and persuade a court that this version is the attractive one. ${ }^{90}$

There are basically three ways for legal researchers to develop patterns. First, the advocate can drill down into particular words and phrases, the same tactic that led Bill Clinton to argue, "It depends on what the meaning of the word 'is' is." 91 This is often fairly easy, since dictionaries invariably offer several synonyms for every definition, each of which recursively leads to still more definitions and synonyms.

Second, acts that are forbidden by one rule may sometimes be authorized and even required by other bodies of law. Here, the main difficulty is to find a second rule broad enough to cover the behavior at issue. ${ }^{92}$ Sometimes this can be easy. For example, intellectual property gives recipients a "lawful monopoly," while antitrust law holds that some (poorly-specified) business methods for exploiting patents are illegal. The

89. For an exhaustive survey of the existing jurisprudence literature, see, e.g., Precedent and Analogy in Legal Reasoning, StAn. EnCYClOPEDIA PHIL. (June 20, 2006), https://plato.stanford. edu/entries/legal-reas-prec/.

90. Scholars have long recognized this incoherence, perhaps most famously in the so-called "canons of construction" for interpreting statutes. Professor Llewellyn famously argued that every canon has a counter-canon, so that judges end with the same discretion they had to begin with. Karl Llewellyn, Remarks on the Theory of Appellate Decisions and the Rules or Canons About How Statutes Are to Be Construed, 3 VAND. L. REV. 395 (1950).

91. Timothy Noah, Bill Clinton and the Meaning of "Is,” SLATE (Sept. 13, 1998), http:// www.slate.com/articles/news_and_politics/chatterbox/1998/09/bill_clinton_and_the_meaning_ of_is.html [https://perma.cc/K2KU-2UMD].

92. The potential for conflict grows when courts are permitted to include supplemental sources like common sense, custom, and public policy in their inquiry. See POSNER, LAW AND LiTERATURE, supra note 4, at 287. One of formalism's most appealing features is that it limits judges to legal texts, making it that much harder to find conflicts. 
result is that there is no gray area: if you guess wrong you not only lose your intellectual property reward, you commit a felony. ${ }^{93}$

Finally, advocates can step back to ask whether the proposed interpretation conflicts with the statute's other provisions or overall purpose. Such inconsistencies are fairly common since no complex text is ever entirely consistent and most legislators are careless. ${ }^{94}$ More fundamentally, different sections may be drafted by different legislators with different intent, so that the overall statutory scheme may never have existed in any one mind at all. Then too, legislators cannot anticipate every fact pattern, so judges sometimes find themselves confronting what Professor Lessig calls "latent ambiguities" "95 that no one anticipated. The Mann Act,${ }^{96}$ RICO,${ }^{97}$ and federal wire fraud ${ }^{98}$ are all examples of statutes that turned out to cover many more fact patterns than Congress anticipated.

\section{Legal Judgment: Choosing the Best Pattern}

We have argued that advocates who look hard enough will almost always find competing patterns. At this point, legal reasoning consists of picking the "best" or "most convincing" one. If law were a Type 2 activity, good lawyers could stand at a white board and demonstrate the right choice to everyone. But of course, this is precisely what they cannot do. ${ }^{99}$ Instead, the best they can do is point out qualitative reasons to choose their pattern in much the same way that art critics admire some works compared to others. ${ }^{100}$ American lawyers typically refer to these characteristically Type 1 narratives as "judgment." A legal realist would presumably call this a smokescreen. However, our "green knife" example argues that Type 1

93. M.J. Adelman \& F.K. Juenger, Patent-Antitrust: Patent Dynamics and Field-of-Use Licensing, 50 N.Y.U. L. REV. 273, 308 (1975).

94. Statutes and constitutions are written in haste by busy people not always of great ability or diligence, and we are not privileged to ignore the hasty and hackneyed provisions and reserve our attention for the greatest. Moreover, they are products of a committee (the legislature) rather than of a single mind, and of a committee whose numerous members may have divergent objectives.... To suppose that its every word probably has significance, that every statute is a seemless whole, misconceives the legislative process.

POSNER, LAW \& LITERATURE, supra note 4, at 248.

95. LAWRENCE LESSIG, CODE 189 ( 2 d ed. 2006).

96. Eric Weiner, The Long, Colorful History of the Mann Act, NPR (Mar. 11, 2008), https:// www.npr.org/templates/story/story.php?storyId $=88104308$.

97. Harold Selan, Interpreting RICO's "Pattern of Racketeering Activity" Requirement After Sedima: Separate Schemes, Episodes or Related Acts?, 24 CAL. W. L. REV. 1 (1987).

98. K. Edward Raleigh, Limiting Mail and Wire Fraud's Scope, 31 CRIM. JuST. 30 (2017).

99. See, e.g., POSNER, LAW AND LITERATURE, supra note 4, at 287 (Logic is especially helpless in the face of "difficult and important cases."). Id. at 286 ("[M]any legal questions cannot be resolved by logical or empirical demonstration. After eighty-two years it is impossible to prove that Lochner was decided wrongly.").

100. $C f$. id. at 288 ("But because the rational arguments of judges, like those of literary critics, fall short of being conclusive when the dispute is a difficult one to resolve by methods of reason."). 
thought often processes enormous amounts of data. Anecdotally, at least, most working lawyers seem to think that judgment conveys valuable information. ${ }^{101}$

\section{Education and Socialization}

Law-and-literature theorists often invoke "education" and "socialization" to inject democratic values into Fish's otherwise elitist "interpretive community." By comparison, universality argues for a humbler role in which education mostly points students to truths they would eventually discover anyway. As The Paper Chase's Professor Kingsfield says,

I call on you, ask you a question and you answer it. Why don't I just give you a lecture? Because through my questions, you learn to teach yourselves. Through this method of questioning and answering, questioning, answering, we seek to develop in you the ability to analyze that vast complex set of facts that constitutes the relationships of members within a given society. Questioning and answering. At times you may feel that you have found the correct answer. I assure you that this is a total delusion on your part. You will never find the correct, absolute and final answer. ${ }^{102}$

Conversely, universality should make us suspicious of more coercive approaches, for example the ferocity that first year law professors bring to instilling the doubtful ${ }^{103}$ idea that contract law is unthinkable without "consideration." "104 There is probably no great harm in this: given how many precedents would have to be uprooted to excise it, the fact that the concept could be changed is mostly theoretical. But we should worry that the same power could be used to slant legal judgments toward specific

101. Levinson, supra note 6, at 384 (In law, not even "radical critics defend the position that any interpretation is as good as any other.").

102. Quoted in Steven Adelman, Transforming Skulls Full of Mush: Venue Management Law School, FACILITY MANAGER (Jan. 6, 2015), http://magazine.iavm.org/article/transforming-skulls-fullof-mush-venue-management-law-school/ [https://perma.cc/6AQ4-JUKT].

103. It is remarkable how quickly senior legal scholars drop the conceit that consideration is inevitable. See, e.g., Comments of Orin K. McMurray, Papers and Discussion Concerning the Redlich Report, 4 AM. L. SCH. REV. 91, 110 (1916) (Law professor who variously taught at Columbia, Michigan, Stanford, and Boalt Law Schools: "Take the doctrine of consideration. A man who is trained merely in the casebooks is very likely to think that he has here something of a character like revelation, something fundamental, absolute, like the truths of mathematics. It is that sort of thing we want to get away from.").

104. Small wonder that Scott Turow's fictitious law school memoir chooses consideration to show not only the sadistic Prof. Perini's abuse of the Socratic method, but also the narrator's cleverness in escaping the trap. S. TUROW, ONE L 192-94 (1977). 
political and cultural outcomes, even if universalism starts to undo these lessons as soon as students begin practicing law. ${ }^{105}$

\section{TOWARD A TYPE 1 THEORY OF LAW: INDIVIDUALS}

We have argued that Type 1 thought (a) is centrally important to legal reasoning, and (b) displays significant universality. The remainder of this Article assumes these facts and traces their implications for lawyers and legal institutions. This Section reviews nineteenth century claims that what we now call Type 1 reasoning should guide policymakers, updates those theories to accommodate the modern evidence for universality, and asks how Type 1 thought shapes the subjective experience of lawyering. Section $\mathrm{V}$ builds on these foundations by analyzing how judicial institutions amplify universality's comparatively weak signals to establish a rough approximation to formalism. ${ }^{106}$

\section{A. Victorian Theory: Shelley, Arnold, and Holmes}

The idea that Type 1 thinking should guide law is nearly as old as the concept of aesthetic or unconscious thought itself. The argument seems to have originated with Percy Shelley, who claimed in 1821 that "poets are the unacknowledged legislators of the World." 107 Logic, he argued, was not strong enough to find solutions to social issues - and particularly not the largest and most important ones. This implied that reason's role in public life, though useful, was mainly to "follow [in] the footsteps of poets, and copy the sketches of their creations into the book of common life."108

Shelley's ideas were only published in 1840, and even then were slow to diffuse. It took another three decades for poet and critic Matthew Arnold to state them definitively. For the most part, his Culture and Anarchy (originally published in 1869) tracks Shelley's argument, albeit with new names so that "reason" is relabeled "science," and "imagination" becomes "culture." 109 However, Arnold also improved on Shelley by

105. Kales, supra note 103, at 111 (According to the Northwestern Law School professor, practicing lawyers look to the law of their states, not what law schools think the law should be. "They never for one moment think of resting the rights of their clients upon Harvard Law School law, or the law of any other law school.").

106. For concreteness, we will assume Prof. Child's $60 \%$ universality estimate in what follows. However, this is probably conservative. First, Child studied visual art, which has no underlying objective truth for experts to converge on. We have already argued that the experience of writing and interpreting legal documents provides an additional and more objective standard for lawyers. Second, Child compared Yale-trained experts to self-taught artists. The convergence would probably have been greater had the latter group been formally educated the way law students are.

107. Shelley, supra note 30, at 508.

108. Id. at 501.

109. Matthew ARNold, Culture AND ANARChy 33-34 (Jane Garnett ed., Oxford Univ. Press 2009) (1869) (Science is the "passion, the sheer desire to see things as they are." Culture by 
admitting that people could disagree about what was beautiful. Building on his earlier work in literary theory, he argued that critics who repeatedly compared new art against recognized "great masters" would eventually reach a consensus. ${ }^{110}$ This collective refinement was especially valuable in politics, where it would stop charismatic individuals from leading society astray on the pattern of the French Revolution. ${ }^{111}$

\section{B. Updating the Theory}

Most of Shelley and Arnold's logic is still viable today. Nevertheless, their argument had a significant defect: for aesthetic judgment to guide law, it must first point in some identifiable direction. But where does this come from? For Shelley and Arnold writing in the nineteenth century, the answer was obvious: the criterion of beauty and the good society already existed in the mind of God. ${ }^{112}$

The question in the twenty-first century is whether Child's more limited and stochastic version of universality can fill this gap. As we argue below, legal institutions provide a natural mechanism for converting weak statistical preferences into quasi-determinate rules. The more serious objection is that Child's evidence is limited to choices between similar images. This suggests that a comparable universality in law probably does not hold for large choices, for example between the U.S. Constitution and Taiwan's. That may explain why common law courts try to change as little doctrine as possible. This restriction is partly enforced by economics: the amount of effort that advocates spend looking for new patterns is limited by litigation budgets on the one hand, and judges' reluctance to learn elaborate new legal theories on the other. Additionally, the rule is also codified in the doctrine of stare decisis. ${ }^{113}$ Significantly, all of these factors are flexible, implying that courts' reluctance to make large changes could undergo at least some evolution over time. ${ }^{14}$

comparison finds "its origin in the love of perfection. . . It moves by the force, not merely or primarily of the scientific passion for pure knowledge, but also of the moral and social passion for doing good.").

110. For a detailed account of Arnold's "touchstone" method of interpretation, see William G. Crane, The Significance of Mathew Arnold's Critical Theory 24 (June, 1920) (unpublished master's thesis, Iowa State University), http://ir.uiowa.edu/etd/4145 [https://perma.cc/42PU-DESB]. Arnold's argument anticipated Child's hypothesis that artisans become experts by making a long series of aesthetic choices.

111. See ARNOLD, supra note 109, at 51 ("[C]ulture, just because it resists this tendency of Jacobinism to impose on us a man with limitations and errors of his own along with the true ideas of which he is the organ, really does the world and Jacobinism itself a service.").

112. Id. at 34 (" $[\mathrm{N}] \mathrm{o}$ action or institution can be salutary and stable which are not based on the will of God.").

113. See PoSner, LAW AND Literature, supra note 4, at 251 (Courts are loath to abandon "even patently erroneous interpretations.").

114. Theoretical physics illustrates how the rules of the game can evolve over time. Down to the early twentieth century, physicists expected new theories to postulate as few changes as possible. In 


\section{The Subjective Experience of Law}

Neural network theory teaches that judges' brains contain elaborate models of the world. Formally, these encode complex equations that assign weights to every possible variable. It follows that the advocate's job is to supply whatever combinations of data garner the biggest response given the judge's limited appetite for learning new patterns. If both advocates knew the judge's underlying equation exactly, one side would always win. But we have seen that, in fact, the full formula is too complicated for humans to understand. This ensures that the strongest side never presents its best argument, opening the door to occasional outcomes in which the weaker side prevails by presenting the stronger of two inherently imperfect arguments.

In fact, the situation is worse than that. Given that advocates often know very little about their judges, ${ }^{115}$ the safest course will often be to assume universality ${ }^{116}$ and write for an average audience. Even then, however, advocates need to worry that their own views might be eccentric. This explains why practicing lawyers endlessly rehearse their arguments to colleagues, trying out new variants to find the most attractive one. ${ }^{117}$

\section{Grand Illusion}

One of legal realism's biggest failings is that it says almost nothing about how lawyers actually practice. Watch oral argument in any courtroom and you will see advocates talk endlessly about "The Law" as if it existed outside themselves. This resembles nothing so much as the old claim that mathematics is never "created" but only "discovered."118

Legal realists, of course, dismiss this as a smokescreen to hide judges' arbitrariness from a credulous public. But in that case, why do lawyers do the same thing in private when there is no public to play to? The better answer is that universality only exists as a statistical quantityand a fairly weak one at that. On the one hand, every lawyer shares a small piece of it, enough to convince her that her own instincts are far better than

1930, however, Wolfgang Pauli invented a new particle (the "neutrino") as what he called a "desperate way out" of several deep problems in nuclear theory. The particle was duly discovered. Fifty years later, theorists routinely postulated large and even infinite numbers of particles. ABRAHAM PAIS, INWARD BOUND: OF MATTER AND FORCES IN THE PHYSICAL WORLD 315 (1986).

115. Most of us are reminded of this fact every December 25, when we learn anew how hard it is to anticipate even close relations' taste in books and clothing. The average advocate has far fewer clues to individual judges' tastes.

116. There is a direct parallel in publishing, where many authors and editors look for stories that they themselves would enjoy without considering how other humans might differ. Stephen M. Maurer, From Bards to Search Engines: Finding what Readers Want from Ancient Times to the World Wide Web, 66 S.C. L. REV. 495, 503-04 (2014).

117. The same principle is used in Hollywood focus groups. Id. at 526.

118. MARIO LIVIO, Is GOD A MATHEMATICIAN? passim (2009). 
the average layperson's. On the other hand, she also knows that her estimates are often wrong. The only way to be sure is to ask other lawyers. Law feels external because, in the deepest sense, it is.

\section{TOWARD A TYPE 1 THEORY OF LAW: INSTITUTIONS}

Superficially, Child's $60 \%$ universality is only $10 \%$ better than a simple coin toss. Whether this matters depends on institutions. For example, $60 \%$ agreement among voters would be a landslide in national politics. ${ }^{119}$ The question for law is how court systems amplify and occasionally garble the signal.

\section{A. What Does "Rule of Law" Require?}

We begin by recalling what democratic theory seeks to accomplish. Congress cannot anticipate every contingency, and only returns to particular topics every few decades. In the meantime, rule of law requires that judges fill the inevitable gaps in ways that do not depart too quickly from what Congress wants. An ideal common law system should therefore be something between a dumb flywheel and a smart-ish autopilot that anticipates how Congress is likely to vote next time. ${ }^{120}$

\section{B. Is Formalism Stable?}

We have argued that lawyers' Type 1 intuitions provide a coherent foundation for quasi-formalist rulemaking. But judges have other options: if they want to, they can equally indulge cronyism or personal politics. Which behavior actually prevails depends on history: as economists say, many equilibria are possible. ${ }^{121}$ Still, we would like to confirm that formalist systems really are equilibria, i.e. that once established they can persist indefinitely. Empirically, there is good anecdotal ${ }^{122}$ and statistical $^{123}$ evidence that real judges respect precedent. But it would be better to have some deeper understanding of why this might be.

119. By the standards of presidential politics, $60 \%$ is nothing short of a landslide. Largest Landslide Victories in US Presidential Election History, WORLD ATLAS, https://www.worldatlas. com/articles/largest-landslide-victories-in-us-presidential-election-history.html [https://perma.cc/ R2A5-RXDN] (60\% of U.S. Presidential elections have been decided by less than $10 \%$.).

120. $C f$. POSNER, LAW AND LiteratURE, supra note 4, at 217 (arguing that discretion need not be "political," but could equally "just be random").

121. For a very short survey of multiple equilibrium ideas in economics, see, e.g., Multiple Equilibria, ENCYCLOPEDIA, https://www.encyclopedia.com/social-sciences/applied-and-social-scien ces-magazines/multiple-equilibria [https://perma.cc/87AF-LG2B].

122. See Posner, How Judges ThinK, supra note 4, at 42-44, 49-50 (reporting that many judges decide cases according to formalist ideals).

123. For one of the rare recent efforts to probe judicial behavior at the trial court level, see Daniel L. Chen, Jens Frankenreiter \& Susan Yeh, Judicial Compliance in District Courts 5 (Toulouse Sch. of Econ., Working Paper No. 16-715, 2016), https://www.tse-fr.eu/publications/judicial-compliance- 
Consider, then, a toy model ${ }^{124}$ where judges seek working lawyers' endorsements for psychic reasons like prestige or material ones like promotion. ${ }^{125}$ How should judges behave? A full analysis would start from the formal economics of repeat games. ${ }^{126}$ Assume however, that lawyers earn their living by negotiating and occasionally litigating business transactions. ${ }^{127}$ Since risk makes deals less attractive, the best way to increase transactions (and lawyer income) is to make them less risky. Formalism does this by divorcing judges' rulings from random cronyism and politics. Strangely, even cronies should dislike cronyism, since the prospect of neutral enforcement makes people more willing to sign contracts with them in the first place. ${ }^{128}$

\section{Cheating}

So far we have assumed that judges who depart from formalist logic are immediately detected. But since universality is stochastic, lawyers

district-courts [https://perma.cc/R67X-4PH8] (finding statistical evidence that US federal lower court cases filed before and resolved after higher court decisions are $29-37 \%$ more likely to rule in the same direction as the appellate court).

124. Social and natural scientists often use deliberately simplistic models to explain mechanisms concisely and point the way toward more complete accounts. See, e.g., Toy Model, WIKIPEDIA, https:// en.wikipedia.org/wiki/Toy_model [https://perma.cc/P936-C6Z9].

125. Professors Epstein, Landes and Posner argue that judicial utility is based on multiple factors that are plausibly consistent with the model presented here. These include internal satisfaction from "feeling that one has done a good job," and the external satisfactions from "reputation, prestige, power, influence, and celebrity" such as the possibility of promotion to a higher court or moving to a high paid private sector job. LeE Epstein, William M. LANDES \& Richard A. POSNER, THE BEHAVIOR of Federal Judges: A THEORETICAL AND EMPIRICAL Study of RATIONAL CHOICE 48 (2013).

126. Economists have modeled the situation in one of two ways. First, they consider trust games in which Alice helps Bob because she thinks he will return the favor. If Bob makes a reciprocal calculation, the assumptions become self-reinforcing even though neither is enforceable. The trust game dynamic is particularly visible when attorneys hire local co-counsel to avoid being "hometowned" in unfamiliar courthouses. Having local counsel present turns what would otherwise be a dangerous one-time transaction into one more installment in the community's repeat interactions. The second set of theories assumes that each actor inherently possesses a fixed amount of trustworthiness which, however, cannot be measured directly. Parties then update their estimates each time a request is or is not honored. For a mathematically rigorous account of repeat game literature, see Luís M. B. Cabral, The Economics of Trust and Reputation: A Primer (June 5, 2005) (preliminary draft) (on file with N.Y.U.), http://pages.stern.nyu.edu/ lcabral/reputation/Reputation_June05.pdf [https://perma.cc/DJ6J-HETJ].

127. The argument assumes that the same lawyers simultaneously write contracts and appear before judges. While this is seldom true for individual lawyers, law firms routinely do both.

128. Of course, our model is only a toy. Many real lawyers make a living by representing nonbusiness clients like tort victims. Furthermore, court systems are embedded in larger institutions. This suggests that judges could decide that it is better to write decisions that pander to the ideology of political parties that might one day promote them. Finally, one can imagine variant models where the cronies are lawyers rather than litigants. Since clients are risk averse, lawyers trying to keep clients happy will normally lose more from downside losses than they gain from upside wins. This suggests that judges are most likely to please counsel on average by adopting split-the-difference strategies that protect both sides against deep losses. 
cannot be sure whether judges who disagree with them are corrupt or just mistaken. This forces them to wait for enough large or repeated departures to confirm dishonesty. But of course, judges also know this, which means that cheaters can postpone discovery by picking and choosing how often they cheat. ${ }^{129}$

\section{Amplification}

Modern versions of universality need institutions to elevate weak signals into system-wide rules. But this is not enough: they should also avoid mistakes. Assume, following Child, that a single judge will arrive at the correct (universal) rule $60 \%$ of the time. Replacing her with a panel improves matters, but only slowly: a three judge panel will have the right answer $65 \%$ of the time, a five judge panel $73 \%$ percent, and so on. ${ }^{130}$

The question is still more complicated when we recall that courts influence each other. Economists typically analyze this kind of dynamic through "social influence" networks where each member starts with some idiosyncratic belief and then modifies it each time she learns what others think. ${ }^{131}$ For example, Alice might influence Bob, who influences Carl, who then closes the circle by influencing Alice. But there could also be a second path in which Alice talks to Carl, who gives his opinion directly back to Alice. This choice of paths necessarily injects a measure of randomness into the calculation. Despite this, most social influence models seem to be well-behaved in the sense that each judge eventually converges on a stable, long-run opinion. ${ }^{132}$

Real life is bound to be messier. Probably the most obvious complication is that courts only write opinions when plaintiffs decide that bringing suit will be cost-effective. This suggests that bad theories can linger for years waiting for a plaintiff that is either sufficiently rich or sufficiently desperate to attempt a revival. ${ }^{133}$ We should also expect

129. Casual observers often accuse judges of ignoring the law. But judges who study an issue for weeks necessarily change their neural networks in the process. This suggests that casual observers will always see things somewhat differently and that judges are more sincere than they seem.

130. The estimate assumes that each judge decides independently, i.e. that no judge consults any other judge before deciding. To the extent that discussion makes judges more receptive to new patterns, the $65 \%$ figure should be seen as a lower bound.

131. Matthew O. JaCKSON, SOCIAL AND ECONOMIC NeTWORKS 228-35 (2008). The belief is conventionally expressed as the probability that some particular event will happen, in our case that a particular proposition of law becomes the majority rule.

132. Economists have also found solutions where members' opinions can oscillate indefinitely. However, this only happens where every path that leads from Alice back to herself is the same length. This is unlikely for real court systems, where the order in which different circuits consider cases is usually random. See id. at 230-33.

133. One of the most spectacular examples derives from antitrust law, where litigants have essentially stopped writing contracts authorized by the Supreme Court's decision in United States $v$. General Electric Co., 272 U.S. 476 (1926), even though the Court has twice declined to overrule it. 
strategic behaviors. These include attempts to change the law through forum shopping and sustained campaigns in which government and advocacy groups continue bringing cases until the law finally changes. ${ }^{134}$

\section{POLICY IMPLICATIONS}

The age-old debate between the legal realists and formalists was never about policy. Indeed, the realists hardly ever denied that formalism and rule of law were desirable - only that they were possible. By comparison, recognizing the centrality of Type 1 processes implies important policy choices. On the one hand, policymakers must now decide which mode works best for each and every legal issue. On the other hand, Type 1 processes are largely unconscious. What can policymakers reasonably do to control bias?

\section{A. Division of Labor: Choosing Between Type 1 and Type 2 Reasoning}

Lawyers value Type 2 proofs for their transparency: being articulable means that anyone can check their logic. At the same time, Type 2 rules are inflexible and for that reason prone to absurdities. ${ }^{135}$ When this happens, judges and advocates can either try to construct a new Type 2 system - as the law-and-economics movement advocates for antitrust ${ }^{136}$ or ask whether a Type 1 solution might work better after all.

Sometimes the answer is clear. For example, psychologists have shown that Type 2 judgments based on formal statistical analyses work better than Type 1 judgments for any problem that can be reduced to an actuarial table. ${ }^{137}$ This suggests that the much-maligned Federal

See, e.g., A.J. Weinschel, Antitrust-Intellectual Property Handbook (2000) (advising practitioners that it is not "prudent" to rely on the case).

134. Law students often wonder why the middle third of their antitrust textbooks consists entirely of cases decided in the 1940s. The reason is the Roosevelt Administration, which saw the "little Depression" of 1937 as evidence that monopolies were strangling the economy. F.D.R. reacted by expanding the Justice Department's Anti-Trust Division from a few dozen lawyers to nearly three hundred. The statute's reach expanded dramatically over the next decade. DAVID M. KENNEDY, FreEdOM From FEAR: THE AMERICAN PEOPLE IN DEPRESSION AND WAR, 1929-1945, 359 (1999).

135. See Posner, LAW AND Literature, supra note 4, at 240-41 ("[A] legal rule that is too specific, may for that reason lack adaptability.").

136. Antitrust law provides the closest analog to policy-based decision-making in modern law. Once the U.S. Supreme Court gave up on per se rules in the late 1930s, every dispute revisited policy more or less from scratch. This must have been tempting since microeconomic theory is both conceptually clear and predictive. Despite this, the results have been widely criticized. See, e.g., Holman Jenkins, Jr., How Justice Went Wrong on AT\&T: Comcast-Type Decrees May Be a Kludge, but They Help to Dissipate the Political Heat, WALL ST. J. (Dec. 17, 2017), https://www.wsj.com/articles/howjustice-went-wrong-on-at-t-1513125457 (Antitrust "pretends to be ... an objective, clinical analysis of competitive conditions" but this only hides "a predisposition to meddle for bureaucratic or political reasons.").

137. See KAHNEMAN, supra note 2, at 234-44. 
Sentencing Guidelines, for example, might be the best choice after all. On the other hand, similarly well-defined problems are rare in law. For closer cases, at least, the psychology evidence suggests that judges should lean toward Type 1 solutions when problems are sufficiently regular to be predictable and common to allow prolonged practice. ${ }^{138}$

When Type 1 methods are desirable, the best way to implement them will be to adopt open-ended inquiries on the pattern of the "reasonable man" standard ${ }^{139}$ in tort law or the various "balancing tests" beloved by constitutional lawyers. ${ }^{140}$ The good news, as we have argued, is that universality will often make these standards more determinate than they seem.

\section{Textualism vs. Intentionality}

This Article has so far focused on the global choice between Type 1 and Type 2 rules. But Type 1 thought is itself subdivided between aesthetic judgments and pattern recognition. This neatly overlaps the traditional division between "intentionalists," who focus on what the original drafters meant, and "textualists" who privilege how ordinary readers understand documents on average. ${ }^{141}$ It is reasonable to think that readers' facilities for pattern recognition can be encouraged by, for example, doctrines that stress historic intent over the reader's own subjective reactions to text. But in that case, which choice should the legal system make? We have emphasized that universality depends partly on aesthetics and partly on pattern recognition, and these will often pull in opposite directions. To the extent that we value determinacy, we should choose whichever form of universality proves strongest.

\section{B. Deciding Close Cases}

Legal scholars have long known that establishing a coherent "middle ground" for interpreting precedent does not guarantee determinate rulemaking. Instead, there will always be "hard cases" where the better

138. See id. at 251 .

139. See, e.g., Panduit Corp. v. Dennison Mfg., Co., 810 F.2d 1561, 1566 (Fed. Cir. 1987) (criticizing "the 'reasonable man' and other ghosts in the law").

140. As Justice Scalia complained, most balancing rules are at least formally indeterminate, telling judges to compare "incommensurable," "unweighted," and "unranked factors" without any "principled metric for deciding" which cases fall within the rule. John F. Manning, Justice Scalia and the Idea of Judicial Restraint, 115 Mich. L. REV. 747, 754-55 (2017).

141. See, e.g., Daniel A. Farber, The Inevitability of Practical Reason: Statutes, Formalism, and the Rule of Law, 45 VAND. L. REV. 533 (1992); John F. Manning, Textualism and Legislative Intent, 91 VA. L. REV. 419 (2005); Caleb Nelson, What is Textualism, 91 VA. L. REV. 347 (2005). 
interpretation is unclear. ${ }^{142}$ The modern understanding of universality suggests that this can happen for two reasons:

Reason 1. Universality only exists statistically, implying that some well-informed individuals will normally dissent. Even when most judges see one view as clearly superior, a few judges may see the choice as indeterminate. Furthermore, the dissenters could well be different for every issue.

Reason 2. Child presented his subjects with pairs in which Ivy League experts overwhelmingly preferred one image to the other. But suppose he had instead selected images where this was untrue? Logically, we would expect "close cases" where experts disagree to be universal as well.

The problem, of course, is that judges who encounter close cases cannot be sure whether they are experiencing "Reason 1" or "Reason 2." From this standpoint, it is probably better for each judge to give her best estimate for the correct outcome even in close cases, so that universality emerges for Reason 1 cases in the usual way. This still leaves the question of what to do about Reason 2 cases. Here, some individual humanpreferably the appellate courts - will have to decide. At the same time, democratic theory suggests that Reason 1 cases should be decided through universality. This means that appellate judges should normally defer to the lower courts once a clear majority emerges.

\section{Guarding Against Prejudice}

The problem with Type 1 judgments is that they are unconscious. This means that we can never be sure when prejudice enters in. Here, universality is a partial corrective since purely personal biases will often cancel each other on average. The larger question is what to do when the prejudices are themselves universal. For example, psychologists have shown that all humans prefer some faces to others. ${ }^{143}$ This makes it reasonable to worry that judges might sometimes rule for the prettiest litigant. Here, the most obvious response is to identify and correct biases using explicitly Type 2 statistical reasoning. The deeper problem is that our logical selves may not understand the patterns that machines find in our Type 1 reasoning. The question will then become whether we trust our machines enough to take corrective action on faith.

142. See Dworkin, supra note 10, at 160-61 ("The distinction between hard and easy cases at law is perhaps just the distinction between cases that do and do not" permit "a unique interpretation" on the basis of fit.); POSNER, LAW AND LITERATURE, supra note 4, at 287 ("[M]aybe reason cannot decide the hard cases.").

143. Renoult, supra note 72 , at 283 (summarizing evidence that humans universally prefer average, symmetric, and sexually dimorphic faces). 


\section{CONCLUSION}

This Article has argued that legal reasoning cannot be analyzed in exclusively logical, Type 2 terms. Instead, Type 1 intuitions play a crucial role in deciding how law evolves. Acknowledging this reality will force policymakers to confront significant new issues, most obviously whether legal doctrine should encourage Type 1 or Type 2 processes in specific cases.

The surprise is universality, i.e. the tendency of lawyers to reach similar judgments no matter what culture they were born into. This provides a natural explanation for the common perception that judges feel significantly constrained by a middle ground that is neither "formalist" nor "legalist." The account is also normatively attractive, since universality seems to depend on shared truths that most practicing lawyers will eventually come to. Apparently, law is more than identity politics after all.

The Victorian vision that aesthetic insights will lead society to the mind of God are gone forever. But we can still hope to build common law systems that are impartial, predictable, and stable against unconscious bias. Compared to the claims of its predecessors, this new formalism is modest, imperfect, and stochastic. No matter. It will do. 